\title{
横流れ不安定特性に影響を及ぼす三次元層流境界層 の要因について*
}

\author{
谷口英 夫*1, 渡 邊 喬*1, 加 藤 景 一*2 \\ Factors of Three-Dimensional Laminar Boundary Layers \\ Affecting the Characteristics of Cross-Flow Instability
}

Hideo TANIGUCHI*3, Takashi WATANABE and Keiichi KATOH

${ }^{* 3}$ Department of Mechanical Engineering, Iwate University, 4-3-5 Ueda, Morioka-shi, Iwate, 020-8551 Japan

\begin{abstract}
The correlations between the characteristic values of the three dimensional boundary layer and the characteristics of the cross-flow instability have studied by a linear stability analysis of the Falkner-Skan-Cooke boundary layers. Several parameters to predict the critical point of the crossflow instability and prediction functions of the critical Reynolds number are suggested. It has been found that new parameter defined in this study is available to predict the critical point of the crossflow instability. It is also shown that the shape factor obtained from the velocity profile of the crossflow velocity component and the non-dimensional cross-flow velocity at the inflection point of the cross-flow velocity profile are available to predict the critical Reynolds number. The wave length of the critical disturbance in the cross-flow direction has been found to be about $3 \sim 4$ times as long as the $1 \%$ boundary layer thickness of the cross-flow velocity profile.
\end{abstract}

Key Words : Stability, Boundary Layer, Transition, Three-Dimensional Flow

\section{1. 緒言}

三次元境界層の乱流遷移を導く主要な不安定と考え られている横流れ不安定については, 円板(1) (3) や円 すい体(4)(5) のような回転軸対称物体上の境界層や, 後 退円柱 ${ }^{(6) \sim(8)}$, 後退くさび(9) (12) といった後退翼を形状 的に模擬する物体上の境界層について研究が行われて きた. 各研究者は, それぞれの特定の流れ場について 横流れ不安定の理論的・実験的研究を行っているが, どのような流れ場が横流れ不安定に対し安定である か, または不安定であるかといった知見はあまり示さ れていない. また, 安定性解析においては, 擾乱を支 配する微分方程式の固有值問題を解くことにより, 擾 乱の特性や臨界レイノルズ数を求めることができる が, それらを決定する層流境界層の要因が特に何であ るかといった知見も示されていないようである。本研 究では, 後退くさび上の三次元境界層 (FalknerSkan-Cooke 流(13)) に対して線形安定性解析を行い, 三次元層流境界層の諸特性值と横流れ不安定特性の関

* 原稿受付 2003 年 10 月 6 日.

*1 正員, 岩手大学工学部( $\boldsymbol{\omega}$ 020-8551 盛岡市上田 4-3-5).

*2 (株) 東北真空技術 ( 039-2245 八户市北インター工業団地 6-1-16).

E-mail : tani@iwate-u.ac.jp
係について調べ, 横流れ不安定特性に大きく関与する 層流境界層の要因を明らかにすることを目的としてい る.

\section{2. 三次元層流境界層と線形安定性解析}

図 1 に全頂角 $\Omega \pi$, 後退角 $\Lambda$ を有する後退くさび上 にとった座標系を示す。このとき境界層の $x_{c}, y_{s} お よ$ び $z$ 方向の速度成分はそれぞれ次のように表される.

$$
\begin{aligned}
& \bar{u}_{c}=U_{e} f^{\prime}(\eta), \bar{v}_{s}=V_{e} g(\eta), \\
& \bar{w}=-\frac{\nu}{\delta}\left(\frac{n+1}{2} f+\frac{n-1}{2} n f^{\prime}\right), \\
& \eta=z / \delta, \delta=\sqrt{\nu x_{c} / U_{e}}, \\
& U_{e}=k x_{c}^{n}[n=\Omega /(2-\Omega), k=\text { const. }], \\
& V_{e}=V_{s \infty}=\text { const. }
\end{aligned}
$$

ここで, レは動粘度を表し, 関数 $f(\eta)$ と $g(\eta)$ は以下 の Falkner-Skan-Cooke 方程式の解である.

$$
\begin{aligned}
& f^{\prime \prime \prime}+\frac{n+1}{2} f f^{\prime \prime}+n\left\{1-\left(f^{\prime}\right)^{2}\right\}=0, \\
& g^{\prime \prime}+\frac{n+1}{2} f g^{\prime}=0, \\
& f(0)=f^{\prime}(0)=g(0)=0, f^{\prime}(\infty)=g(\infty)=1
\end{aligned}
$$




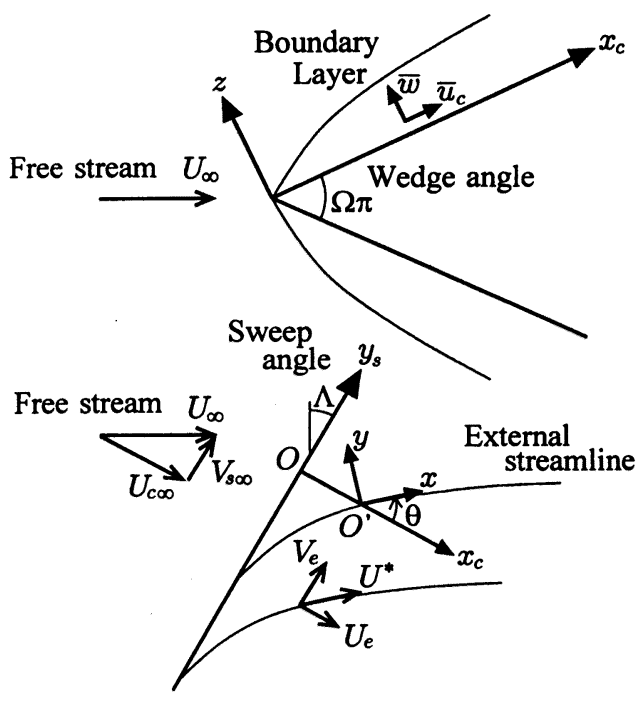

Fig. 1 Coordinate systems

次に, $x_{c}, y_{s}$ 方向の境界層外縁速度の比 $a$ と合成速 度 $U^{*}$ を次のように定義し, 外部流線方向に座標系を 反時計回りに $\theta$ だけ回転した新たな座標系 $(x, y, z)$ を考える。

$$
a=V_{e} / U_{e}=\tan \theta, \quad U^{*}=\sqrt{U_{e}^{2}+V_{e}^{2}}
$$

このとき, $x$ および $y$ 方向の無次元速度成分 $U$ およ び $V$ はそれぞれ次のように表される.

$$
\begin{aligned}
& U(\eta)=\frac{\bar{u}}{U^{*}}=\frac{1}{1+a^{2}}\left(f^{\prime}+a^{2} g\right), \\
& V(\eta)=\frac{\bar{v}}{U^{*}}=\frac{a}{1+a^{2}}\left(g-f^{\prime}\right)
\end{aligned}
$$

さらに, 本研究では安定性解析結果を一般的に議論す るために, 無次元座標 $\eta$ の代わりに, 速度成分 $U$ か ら得られる境界層排除厚さ $\delta_{x}^{*}\left[=\delta \int_{0}^{\infty}(1-U) d \eta\right]$ で 垂直方向座標 $z$ を新たに無次元化した無次元座標 $\eta^{*}\left(=z / \delta_{x}^{*}\right)$ を使用する。図 2 は, $\left(x, y, \eta^{*}\right)$ 座標系に おける境界層内の速度分布を模式的に描いたものであ る.

図 2 に示す流れ場の安定性解析には, 境界層外縁速 度 $U^{*}$, 境界層排除厚さ $\delta_{x}^{*}$ を用いて無次元化した次 の Orr-Sommerfeld 方程式と境界条件を用いて行っ た.

$$
\begin{aligned}
& \left\{\left(\alpha^{*} U+\beta^{*} V\right)-\gamma^{*}\right\}\left\{D^{2}-\left(\alpha^{* 2}+\beta^{* 2}\right)\right\} w \\
& \quad-\left(\alpha^{*} D^{2} U+\beta^{*} D^{2} V\right) w \\
& \quad=\frac{1}{i \operatorname{Re} e^{*}}\left\{D^{2}-\left(\alpha^{* 2}+\beta^{* 2}\right)\right\}^{2} w \quad \cdots \cdots \cdots \cdots \cdots \\
& \eta^{*}=0: w=D w=0, \quad \eta^{*} \rightarrow \infty: w, D w \rightarrow 0
\end{aligned}
$$

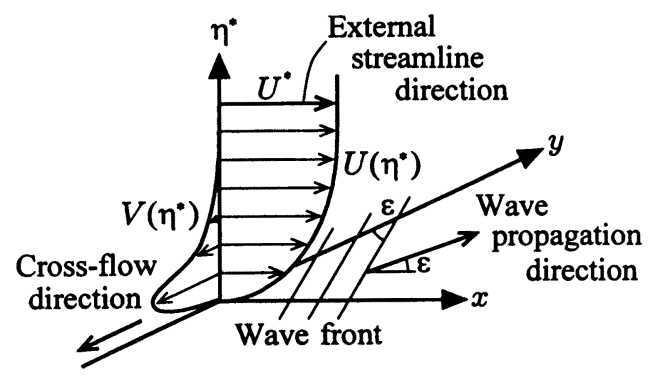

Fig. 2 Sketch of flow situation

ここで, $D \equiv d / d \eta^{*}$ であり, $w$ は垂直方向擾乱速度成 分の振幅を表す.さらに, $\alpha^{*}$ および $\beta^{*}$ はそれぞれ $x$ および $y$ 方向の角波数を表し, $\gamma^{*}$ は角周波数, $R e^{*}$

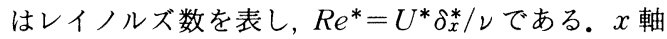
から $y$ 軸方向へ反時計回りに測ったとき, 擾乱の伝播 方向と $x$ 軸とのなす角度 $\varepsilon$ は $\varepsilon=\tan ^{-1}\left(\beta^{*} / \alpha^{*}\right)$ と表 される.また, 角度 $\varepsilon$ は擾乱の波面と $y$ 軸とのなす角 度でもある. 式( 5 ) の固有值問題 $E\left(R e^{*}, \alpha^{*}, \beta^{*}, \gamma^{*}\right)$ $=0$ は, シューティング法 ${ }^{(4)(14)}$ を用いて数值的に解析 した。

\section{3. 計算結果および考察}

本研究では, 圧力勾配パラメータ $n=1,1 / 3$ および $1 / 7$ (全頂角 $\pi, \pi / 2$ および $\pi / 4$ ) の三つの場合を対象に し, 外部流線方向 $\theta$ については, $10^{\circ} お き に 10 〜 80^{\circ}$ と $45^{\circ}$ の九つの場合について, 安定性解析を行ってい る. 得られる安定性解析結果と層流境界層の様々な諸 特性值との間の相関関係を調べることにより，横流れ 不安定特性に大きく影響を及浑す層流境界層の要因に ついて明らかにしていく.

$3 \cdot 1$ 層流境界層の速度分布 図 3 および図 4 は, 圧力勾配パラメータ $n=1$ の場合における外部流線方 向および横流れ方向の速度成分の垂直方向分布を外部 流線方向 $\theta$ の各值に対して示したものである. 図 3 の外部流線方向速度成分 $U\left(\eta^{*}\right)$ については, 外部流 線方向の角度 $\theta$ が大きくなるにしたがい, 壁面におけ

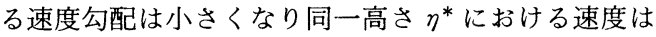
低下するのに対して, 境界層外縁付近では逆に速度が 大きくなる傾向を示している.

横流れ速度成分 $V\left(\eta^{*}\right)$ については，式(4)の第二 式の性質を反映して圧力勾配パラメータ $n$ が同じで あれば, 外部流線方向 $\theta$ に対しては全て相似な分布と なる. 式 ( 4 )の第二式中の関数 $\left[g(\eta)-f^{\prime}(\eta)\right]$ は圧力 勾配パラメータ $n$ にのみ依存するので, $V(\eta)$ の大き さは外部流線方向が関係する係数 $a /\left(1+a^{2}\right)$ により変 


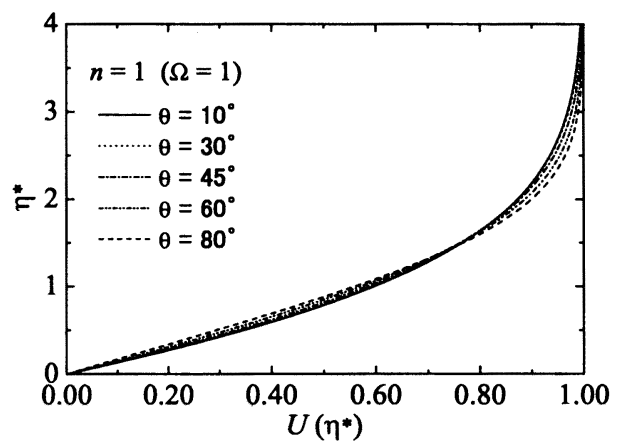

Fig. 3 Wall-normal profiles of streamwise velocity

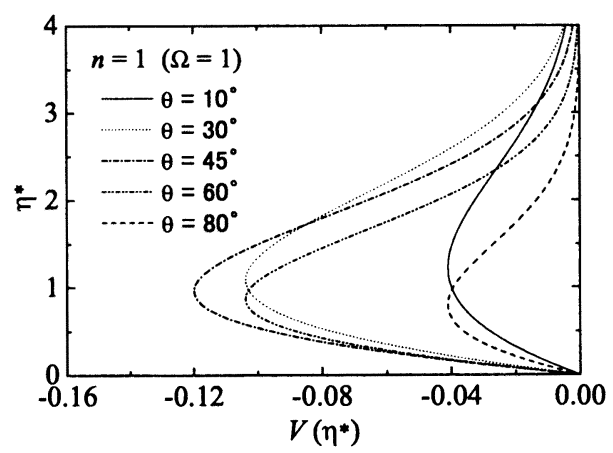

Fig. 4 Wall-normal profiles of cross-flow velocity

化する.このため, 各 $\theta$ の值における $|V|$ の最大值 $|V|_{\max }$ は, $\theta=45^{\circ}$ のとき最も大きくなり, $\theta=45^{\circ}$ $\pm b\left(0<b<45^{\circ}\right)$ のときは同じ $|V|_{\max }$ の值をとる.た だし, 安定性解析においては, 境界層排除厚さ $\delta_{x}^{*}$ を 基準とした座標系 $\eta^{*} て ゙$ 表される速度分布 $V\left(\eta^{*}\right)$ を 使用するので, $\theta=45^{\circ} \pm b\left(0<b<45^{\circ}\right)$ では同一の横 流れ速度分布とはならず, 図 4 に示すように, $|V|_{\max }$ を示す $\eta^{*}$ の位置は外部流線方向 $\theta$ が大きくなるにし たがい，壁面側に近づいてくる傾向を示している.

外部流線方向 $\theta$ を一定として, 圧力勾配パラメータ $n$ の值を変えた場合, 外部流線方向速度成分 $U\left(\eta^{*}\right)$ の垂直方向分布に及ぼす圧力勾配パラメータnの影 響は小さく, あまり分布形状に変化は見られなかっ た。一方, 横流れ速度成分 $V\left(\eta^{*}\right)$ については, 当然な がら, 圧力勾配パラメータ $n$ の值が小さくなるにした がい横流れ速度が減少していき， $|V|_{\max }$ が小さくなる ことを示した。

$3 \cdot 2$ 臨界点における各特性值 本解析から得ら れた臨界レイノルズ数 $R e_{c}^{*}$ と外部流線方向 $\theta$ の関係 を図 5 に示す. 図 5 から, 圧力勾配パラメー夕nが小 さくなるにしたがい $\theta$ の各値において, $R e_{c}^{*} か ゙$ 増加 することが分かる．これは, 弦方向(図 2 の $x_{c}$ 方向)

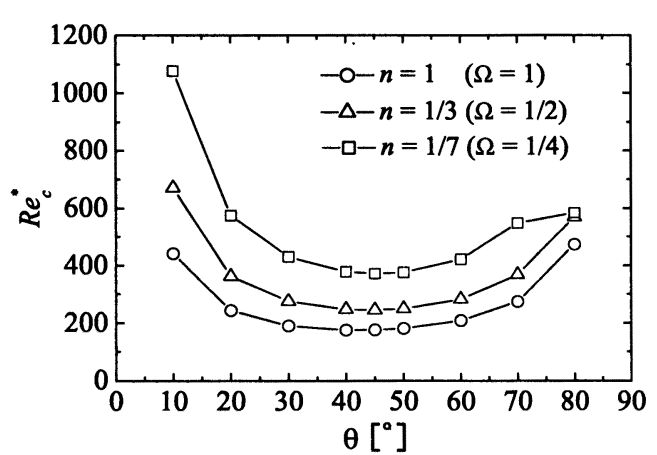

Fig. 5 Critical Reynolds numbers

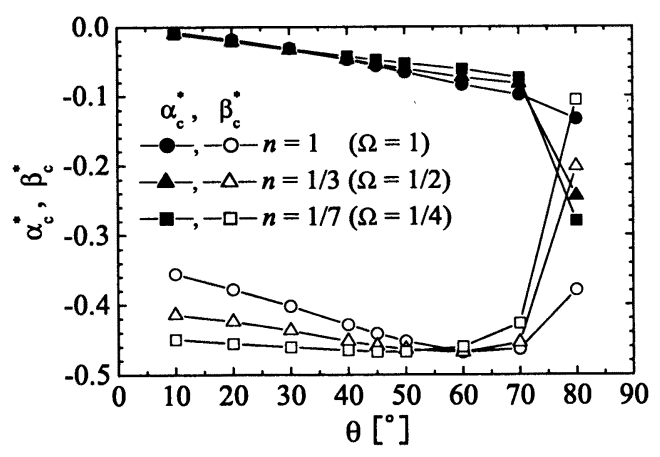

Fig. 6 Critical wave numbers

の圧力勾配が小さくなるにしたがい, 流れが安定化す ることを示している. また， $n$ の各值に対する $R e_{c}^{*}$ と $\theta$ の関係については, $\theta=40 \sim 50^{\circ}$ の範囲において $R e_{c}^{*}$ が最小值をとり, その角度から離れるにしたがい $R e_{c}^{*}$ が増加することを示している. しかし, $n=1 / 7$ においては, $\theta$ が $70^{\circ}$ から $80^{\circ}$ に変化しても $R_{c}^{*}$ はあ まり増加していない. 臨界点における損乱の波数およ び位相速度の解析結果については次の図 6 および図 7 で示すが, $n=1 / 7, \theta=80^{\circ}$ の際の臨界点における擾乱 の $x$ 方向の角波数 $\left|\alpha_{c}^{*}\right|$ および位相速度 $\gamma_{c}^{*} / \alpha_{c}^{*}$ はそれ ぞれ 0.3 および 0.4 となり, 平板境界層の粘性形不安 定における臨界点の值(それぞれ 0.34 および 0.39 ) と 非常に近い值を示した. したがって, 圧力勾配パラメ 一夕 $n=1 / 7$, 外部流線方向 $\theta=80^{\circ}$ の流れ場は横流れ 不安定よりも粘性形不安定が支配的であるものと考元 られる。

図 6 は, 臨界点における外部流線方向および横流れ 方向の擾乱の角波数 $\alpha_{c}^{*} お$ よ゙ $\beta_{c}^{*}$ と外部流線方向 $\theta$ との関係を示している. 図 6 から分かるように, 外部 流線方向の擾乱の角波数 $\left|\alpha_{c}^{*}\right|$ は圧力勾配パラメー夕 $n$ の值によらず, 外部流線方向の角度 $\theta$ が大きくなる にしたがって, 緩やかに大きくなる傾向を示してい 


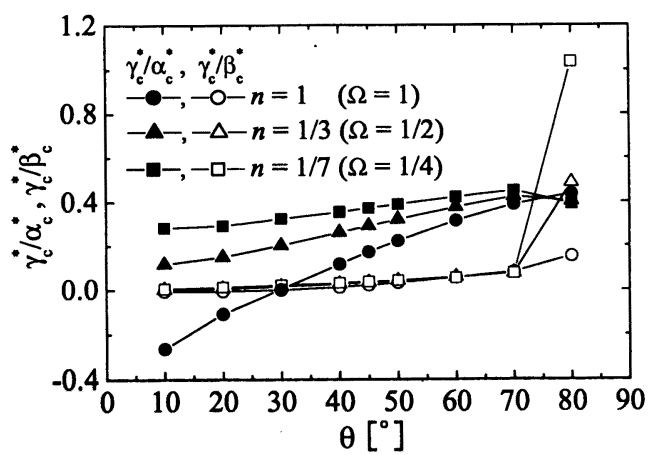

Fig. 7 Phase velocities at critical points

る.しかし, $n=1 / 3$ および $1 / 7$ の $\theta=80^{\circ}$ の場合にお いては, $\left|\alpha_{c}^{*}\right|$ はさらに急激に増加している. 一方, 横 流れ方向の擾乱の角波数 $\left|\beta_{c}^{*}\right|$ は圧力勾配パラメータ $n$ の值によらず，外部流線方向の角度 $\theta$ が大きくなる にしたがって緩やかに増加するが, $\theta=60^{\circ}$ を境に減 少に転じる．特に， $n=1 / 3$ および $1 / 7$ の $\theta=80^{\circ}$ の場 合には, $\left|\beta_{c}^{*}\right|$ の急激な減少が観察される.

図 7 は, 臨界点における外部流線方向および横流れ 方向の擾乱の位相速度 $\gamma_{c}^{*} / \alpha_{c}^{*}$ および $\gamma_{c}^{*} / \beta_{c}^{*}$ と外部流 線方向 $\theta$ との関係を示している. 図 7 から分かるよ うに, 圧力勾配パラメータ $n$ の值によらず, 外部流線 方向の角度 $\theta$ が大きくなるにしたがって, $\gamma_{c}^{*} / \alpha_{c}^{*}$ は増 加する傾向を示しているが, $n$ が小さくなるにつれ， その増加の割合は小さくなっていく．さらに, $n=1 / 3$ および $1 / 7$ の $\theta=80^{\circ}$ の場合には一転減少し, 約 0.4 という平板境界層の粘性形不安定における臨界位相速 度の值 $(0.39)$ と非常に近い值を示す.一方, 横流れ方 向の擾乱の位相速度 $\gamma_{c}^{*} / \beta_{c}^{*}$ は $\theta=10^{\circ}$ から $70^{\circ}$ ま゙, ほほ 0 から 0.08 へ非常に緩やかに増加していき, 圧力勾配パラメータ $n$ の值による違いはほとんど見 られない. しかし， $\theta=80^{\circ}$ になるとその様子は異な り, $n$ が小さいほど大きな増加を示すようになる.

図 8 は, $n=1$ および $1 / 7$ の場合における臨界擾乱 の外部流線方向速度成分の振幅分布および位相分布を $\theta=70^{\circ}$ およ゙ $80^{\circ}$ に対して示したものである.図 8 ( a )の $n=1$ の場合では, 振幅分布の形状には外部流 線方向 $\theta$ による大きな違いは見られないが, 位相分布 においては, $\theta=80^{\circ}$ の場合, $\eta^{*}=3$ 付近において約 $180^{\circ}$ のゆくりした位相変化が観察される. 一方, 図 8 ( b ) の $n=1 / 7$ の場合では, 振幅分布の形状は外部流 線方向 $\theta$ により大きく異なり, $\theta=80^{\circ}$ の振幅分布は 粘性形不安定の TS 波と類似した分布形状を示してい る.さらに, $\theta=80^{\circ}$ の位相分布においては, $\eta^{*}=2$ 付 近において急激な $180^{\circ}$ の位相変化が観察され, 粘性

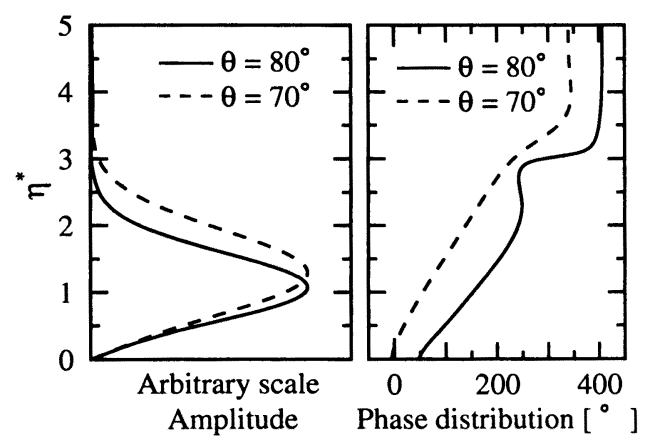

(a) $n=1(\Omega=1)$

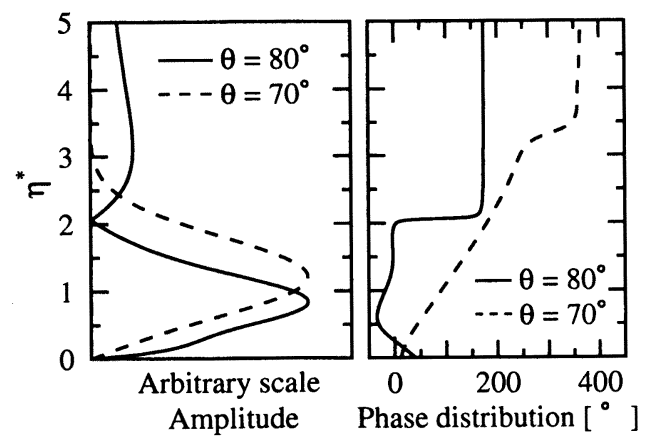

(b) $n=1 / 7(\Omega=1 / 4)$

Fig. 8 Amplitude and phase distributions of the velocity component in the direction of the external streamline of the critical disturbances

形不安定の特徴を示している.

本解析では Orr-Sommerfeld 方程式を用いている ため, 横流れ不安定と粘性形不安定を厳密に分離して 議論することはできないのであるが, 図 5〜8の解析 結果から類推すると, 外部流線方向 $\theta=80^{\circ}$ の流れ場 は横流れ不安定よりも粘性形不安定が支配的に働いて いるものと推察することができる.

$3 \cdot 3$ 臨界点の予測パラメータと臨界レイノルズ数 の予測関数 図 5 に示したように, 圧力勾配パラメ 一夕 $n$ や外部流線方向 $\theta$ の值が変わると層流境界層 の速度分布が変わるためにそれに応じて, 臨界レイノ ルズ数 $R e_{c}^{*}$ も様々に変化する. 本研究では, 数值解 析から得られた臨界レイノルズ数 $\operatorname{Re}_{c}^{*}$ の結果と層流 境界層の様々な諸特性值との間の相関関係を調べるこ とにより, 層流境界層の諸特性値から横流れ不安定の 臨界点を予測するパラメータおよび臨界レイノルズ数 の予測関数の作成を試みた。

まず, 数值解析から得られた $N$ 種類の流れに対す る臨界レイノルズ数を $Y_{i}(i=1, \cdots, N)$, 臨界レイノル 
ズ数の予測関数を $Y=Y(\xi), \xi$ を臨界レイノルズ数 を支配するパラメータとし， $Y \xi=C$ (定数)を満足す るパラメー夕ほを調べる.もし, そのようなパラメー 夕 $\xi$ が見つかれば, $Y=C / \xi$ は臨界レイノルズ数の 予測関数を表し, $Y \xi$ (=定数)は臨界点を予測するパ ラメータとして利用できることになる。

ここでは, パラメータ $\xi$ の満足度を次から得られる 值で評価する。

$$
R=\frac{1}{N} \sum_{i=1}^{N} \frac{\sqrt{\left(Y-Y_{i}\right)^{2}}}{Y}
$$

このRの值が小さいほど, 臨界レイノルズ数を予測 するのに適したパラメータと言える. 本研究では, 27 種類の流れ場の安定性解析を行っているので, $N=27$ である. 実際, 定数 $C$ は, それぞれの層流境界層の諸 特性值から得られるパラメー夕 $\xi_{i}(i=1, \cdots, N)$ と臨 界レイノルズ数の計算值 $Y_{i}$ との積の平均として求め るゆえ, 式 (6) は次のように $C$ に対する平均偏差と 平均值との比として表すことができる.

$$
\begin{aligned}
& \frac{1}{N} \sum_{i=1}^{N} \frac{\sqrt{\left(Y-Y_{i}\right)^{2}} \xi_{i}}{Y \xi_{i}}=\frac{1}{N} \sum_{i=1}^{N} \frac{\sqrt{\left(C-Y_{i} \xi_{i}\right)^{2}}}{C} \\
& =\frac{\frac{1}{N} \sum_{i=1}^{N}\left|C-Y_{i} \xi_{i}\right|}{C} \\
& =\frac{\text { Avarage deviation }}{\text { Avarage value }}
\end{aligned}
$$

図 9 は, 本研究において $R$ 値が小さいと判明した 上位三つの臨界点予測パラメー夕の值を外部流線方向 $\theta$ に対して示している. 図 9 中の添字inf は, 横流れ 速度成分 $\bar{v}$ の変曲点の位置における值を表す.また, $H_{y}$ は横流れ速度成分 $\bar{v}$ から得られる形状係数であ り, 次式で定義する.

$$
H_{y}=\frac{\delta_{y}^{*}}{\theta_{y}}=\frac{\left|\int_{0}^{\infty} \bar{v} / U^{*} d z\right|}{\int_{0}^{\infty}\left(\bar{v} / U^{*}\right)^{2} d z} .
$$

なお, 図 $9(\mathrm{a}) \sim(\mathrm{c})$ の縦軸は, 平均值からデータが どれだけばらついているかを比較できるようにいずれ も平均値の 2 倍までとるように表している. 図 9 から 分かるように，（a）から（c）にいくにしたがいパラメ 一夕值の平均值からのずれが小さくなっていくことが 分かる.また, 図 9(a)〜 ( c ) のいずれの場合におい ても, $\theta=80^{\circ}$ においてパラメー夕値が平均値から大 きくずれていることが分かる. 特に, 圧力勾配パラメ ータ $n$ の值が小さいほどそのずれは大きい.これは

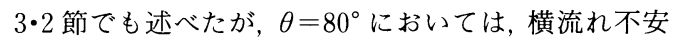
定よりも粘性形不安定が支配的に働いているからだと 考えられる. $\theta=80^{\circ}$ のデータを除けば, パラメータ 值はほほ平均値周りに分布しており, 特に図 9(c)の

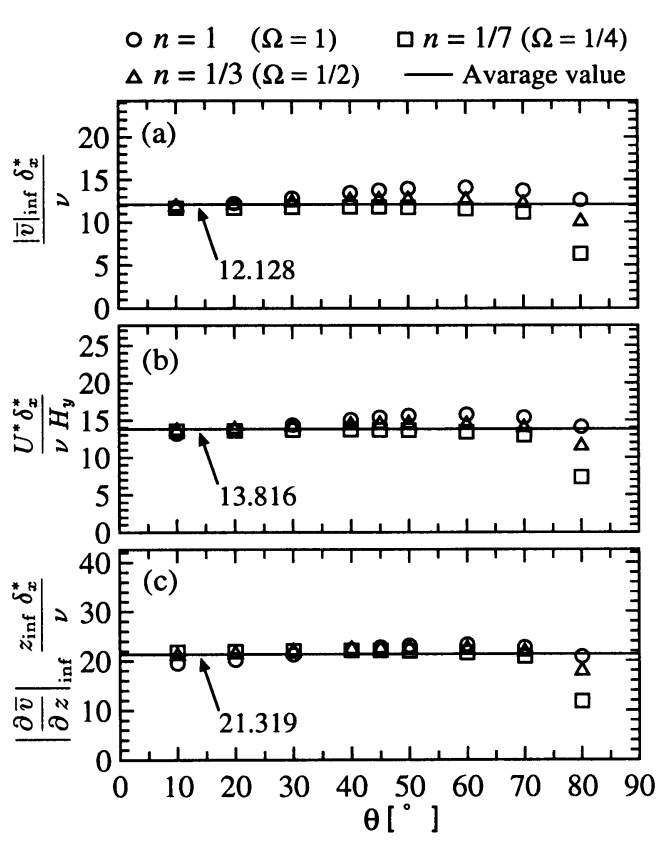

Fig. 9 Prediction parameters of critical point

場合については平均値からのずれが非常に小さい.し たがって, 図 9(c)の縦軸に示したパラメータは横流 れ不安定の臨界点を予測するパラメータに非常に適し ていることを示している.

図 9(c)の縦軸のパラメー夕は, 本研究で新たに考 案したパラメータであり, 横流れ速度分布の変曲点位 置 $z_{\mathrm{nf}}$ およびその位置における外部流線方向渦度成分 の主要項 $|\partial \bar{v} / \partial z|_{\mathrm{Inf}}$, 外部流線方向速度成分から得ら

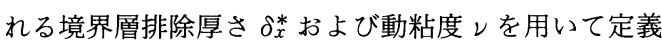
したものである。このパラメータの発想は, 自由せん 断流の乱流遷移過程における渦層の巻き上がり現象か らきている．巻き上がり現象の際には，初め渦層は上 下に波打ち，その後ある渦が周りの渦を巻き込んで大 きな渦へと成長していく，このとき，渦度が大きいほ ど, かつ, 渦層の上下の波打ちが大きいほど渦の成長 過程は早いものと推測される。ところで, 横流れ速度 分布 $\bar{v}(z)$ の変曲点位置 $z_{\text {inf }} に は$, 渦度の大きい“強 い渦層”が存在する。この渦層が壁面から遠い $\left(z_{\mathrm{inf}}\right.$ が大きい) ほど渦層は上下への波打ちが容易になり流 れは不安定になりやすく, 壁面に近い $\left(z_{\operatorname{lnf}}\right.$ が小さい) ほどその運動が制限され流れは安定化すると考えた. また, その “強い渦層” の渦度が大きいほど流れは不 安定になりやすいものと考えた。図 10 は, この考え を模式的に描いたものである.図 $9(\mathrm{c})$ の数值結果は, このような発想で作成したパラメータが横流れ不安定 


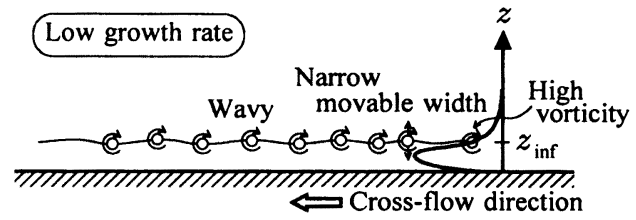

(a) Case of the inflection point near the wall

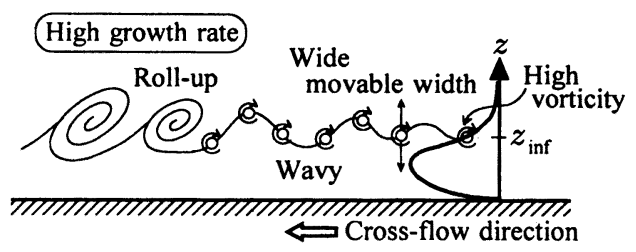

(b) Case of the inflection point far the wall

Fig. 10 Factors affecting the growth of cross-flow in. stability

の臨界点の予測に十分利用できることを示唆している ものと考える.

表 1 は, 臨界レイノルズ数の予測関数と式 (6)の $R$ 值を示したもので, 本研究において $R$ 值が比較的低 い値を示したものを抜粋して $R$ 値の低い順に並べて 示している．表 1（a）は粘性形不安定が支配的である と推察される $\theta=80^{\circ}$ における臨界レイノルズ数も含 めた場合の結果であり, 表 1 ( b ) は $\theta=80^{\circ}$ のデー夕 を除外した場合の結果である。表 1 から明らかなよう に, $\theta=80^{\circ}$ のデータを考慮しても無視しても臨界レ イノルズ数の予測関数に対する $R$ 值の低い順番に違 いは見られないが, $\theta=80^{\circ}$ のデー夕を除外すると $R$ 值は小さくなり横流れ不安定の臨界レイノルズ数の予 測関数としての適合性が増すように見受けられる．表 1 中の上三つの式は, 図 9 に示したパラメータをもと に作成したものである。また，表 1 中最下部の式は， Poll の横流れパラメー夕(6)をもとに作成したもので ある.Poll の横流れパラメータは，しばしば横流れ不 安定の臨界点を予測するパラメータとして紹介される ことがあるが, 表 1 中に示す予測関数の中で $R$ 值が 最も大きく，臨界点を予測するパラメータとしてはあ まり適切でないことが分かる. 一方, 横流れ速度成分 から得られる形状係数 $H_{y}$ や変曲点位置における無次 元横流れ速度 $\bar{v}_{\text {inf }} / U^{*}$ でも横流れ不安定の臨界レイ ノルズ数を予測するのに十分利用できることを表 1 は 示している. 表 1 に示した変数は臨界レイノルズ数の 数値結果と高い相関值を示したものであるが, 結局, 表 1 中の上三つの変数が横流れ不安定の臨界レイノル ズ数の決定に大きな影響を及ぼすものと考えられる.

表 1 に示した臨界レイノルズ数の予測関数を, 静止
Table 1 Various prediction functions of $R e_{c}^{*}$

(a) Case of included datum of $\theta=80^{\circ}$

\begin{tabular}{|c|c|}
\hline Prediction function of $R e_{c}^{*}$ & $\mathrm{R}[\%]$ \\
\hline $21.319 /\left(\left|\frac{\partial \bar{v}}{\partial z}\right|_{\mathrm{inf}} \cdot \frac{z_{\mathrm{inf}}}{U^{*}}\right)$ & 5.98 \\
\hline $13.816 \cdot H_{y}$ & 6.40 \\
\hline $12.127 /\left(|\bar{v}|_{\mathrm{inf}} / U^{*}\right)$ & 7.48 \\
\hline $19.898 /\left(|\bar{v}|_{\max } / U^{*}\right)$ & 10.00 \\
\hline $11.934 /\left(\left|\frac{\partial \bar{v}}{\partial z}\right|_{\mathrm{inf}} \cdot \frac{\delta_{x}^{*}}{U^{*}}\right)$ & 10.91 \\
\hline $43.033 /\left(\left|\frac{\partial \bar{v}}{\partial z}\right|_{\max } \cdot \frac{\delta_{x}^{*}}{U^{*}}\right)$ & 12.15 \\
\hline $78.873 /\left(\frac{|\bar{v}|_{\max }}{U^{*}} \cdot \frac{z_{1 \%}}{\delta_{x}^{*}}\right)$ & 14.75 \\
\hline
\end{tabular}

(b) Case of excluded datum of $\theta=80^{\circ}$

\begin{tabular}{|c|c|}
\hline Prediction function of $R e_{c}^{*}$ & $\mathrm{R}[\%]$ \\
\hline $21.877 /\left(\left|\frac{\partial \bar{v}}{\partial z}\right|_{\text {inf }} \cdot \frac{z_{\text {inf }}}{U^{*}}\right)$ & 2.88 \\
\hline $14.169 \cdot H_{y}$ & 4.50 \\
\hline $12.433 /\left(|\bar{v}|_{\text {inf }} / U^{*}\right)$ & 5.52 \\
\hline $20.400 /\left(|\bar{v}|_{\max } / U^{*}\right)$ & 8.31 \\
\hline $12.069 /\left(\left|\frac{\partial \bar{v}}{\partial z}\right|_{\text {inf }} \cdot \frac{\delta_{x}^{*}}{U^{*}}\right)$ & 9.40 \\
\hline $43.444 /\left(\left|\frac{\partial \bar{v}}{\partial z}\right|_{\max } \cdot \frac{\delta_{x}^{*}}{U^{*}}\right)$ & 10.60 \\
\hline $81.940 /\left(\frac{|\bar{v}|_{\max }}{U^{*}} \cdot \frac{z_{1 \%}}{\delta_{x}^{*}}\right)$ & 11.67 \\
\hline
\end{tabular}

流体中の回転円板 ${ }^{(1)}$ や回転軸対称物体 ${ }^{(16)}$ に沿う三次 元境界層においても有効であるかどうかを調査した。 その結果, 本研究で新たに考案した予測関数(表 1 中 最上部の式) が安定性解析から得られる数值結果と最 も近い值を示したのであるが, 数值結果より約 30\%低 い值を示した. また, 表 1 中のそれ以外の予測関数に 関しては, 数值結果より $40 \%$ 以上低い值を示す結果と なった。この背景には，横流れ速度成分の違いが考え られる. 静止流体中の回転円板(1) ${ }^{(1)}$ 回転軸対称物 体 ${ }^{(16)}$ に沿う三次元境界層の場合, 後退くさび上の三 次元境界層よりも横流れ速度成分が最大值で比較して $50 \%$ 以上大きい. 表 1 中の予測関数は, 横流れ速度成 分をもとに構成されているので, 横流れの影響を過大 に評価したために臨界レイノルズ数を低く見積もった 


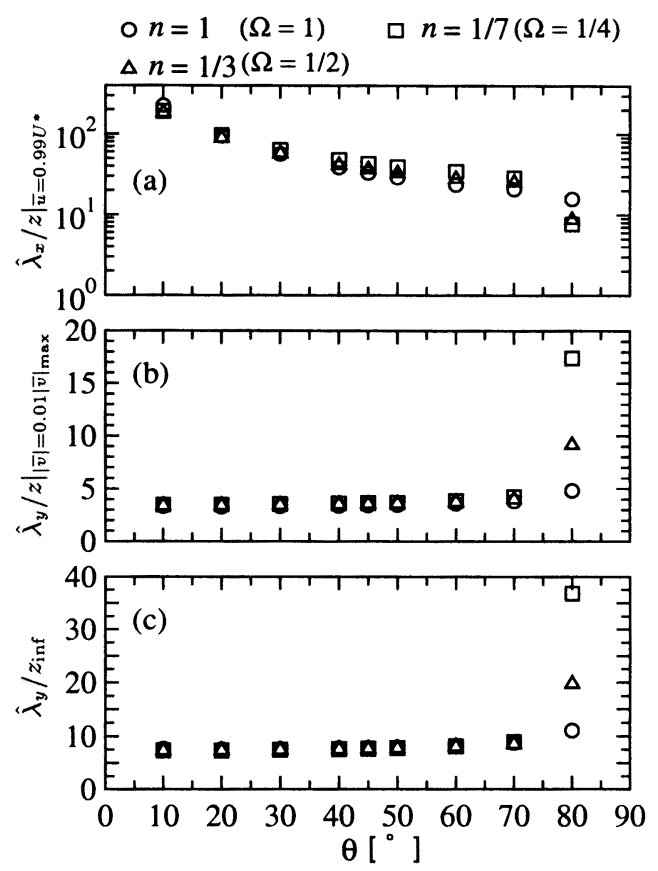

Fig. 11 Wave lengths of critical points

ものと考えられる.したがって, 横流れ速度成分が後 退くさび上の三次元境界層よりも大きい場合には，表 1 中の予測関数は実際の数值結果よりも低い値を示す 傾向にあるということを考慮しておかなければならな ().

$3 \cdot 4$ 擾乱の波長を決定する要因図 11 は, 数值 解析から得られた臨界点における外部流線方向 $(x)$ お よび横流れ方向 $(y)$ の擾乱の波長を外部流線方向 $\theta$ を横軸にとり表している。なお，図 11 に示した波長 は, 層流境界層における特徴的な長さスケールと相関 関係があるかどうか分かりやすく示すためにそれらと の比として表している. 図 11( a )の $x$ 方向の擾乱の 波長は, 外部流線方向速度成分 $\bar{u}$ が外部ポテンシャ 儿速度 $U^{*}$ の $99 \%$ になる位置(外部流線方向 $99 \%$ 境界 層厚さ)との比として表しているが, 外部流線方向 $\theta$ の変化に伴い大きく異なる值をとることを示してい る.すなわち, $x$ 方向の擾乱の波長は外部流線方向 99\%境界層厚さと相関関係はほとんどないということ が分かる. 他の長さスケールとの相関関係についても 調べてみたが, 現在のところ, $x$ 方向の擾乱の波長を 決定する要因についてはいまだに特定には至っていな い.

図 11(b)，(c)の $y$ 方向の擾乱の波長は，それぞれ 横流れ速度成分 $\bar{v}$ が境界層外縁付近で $1 \%$ になる位
置(横流れ方向 1\%境界層厚さ) および変曲点位置との 比として表したものである. 図 11 ( b )，（c）から明ら かなように $\theta=10 \sim 70^{\circ}$ の範囲においては, $\theta$ に対し てほとんど值の変化は見られず, その值は図 $9(\mathrm{~b})$, (c)についてはそれぞれ $3 \sim 4$ および 7〜8 となる. $\theta$ $=80^{\circ}$ では横流れ不安定よりも粘性形不安定が支配的 であると考えられるので, $\theta=80^{\circ}$ におけるデー夕を 除外して考察すると, 横流れ不安定の臨界点における 擾乱の横流れ方向の波長は, 横流れ方向 1\%境界層厚 さの 3〜 倍, 変曲点位置の 7〜8 倍であるということ が分かる.一般に, 横流れ不安定場には, 横流れ渦と 呼ばれる渦が発生することが知られている(15).この 横流れ渦の高さ方向のスケールはだいたい境界層厚さ 程度であるので, 横流れ渦は横流れ方向に $3: 1 \sim 4: 1$ の楕円形状を成して存在していると推察することがで きる.

最後に, 臨界点における擾乱の伝播方向や波面の方 向と層流境界層が示す代表的な方向との間に相関関係 がないかどうかを調査した. しかし，それらの擾乱の 方向を決定するような要因を層流境界層の特性值から 明らかにすることはできなかった. 特に, 擾乱の伝播 方向と横流れ速度分布の変曲点における速度べクト ル, 波面の方向と渦度ベクトルおよび最大渦度べクト ルはほとんど関係がないことが分かった. 多くの場 合, 臨界点における擾乱の波面はほとんど外部流線方 向に平行でわずかに横流れ方向に傾く傾向を示した.

\section{4. 結 論}

三次元境界層の横流れ不安定特性に大きく関与する 層流境界層の要因を明らかにするため, 本研究では, 後退くさび上の三次元境界層 (Falkner-Skan-Cooke Flow)の線形安定性解析を行い, 層流境界層から得ら れる様々な特性值と横流れ不安定特性との相関関係を 調べ, 以下のような知見が得られた。

（1）本研究において新たに考察したパラメータ [図 8(c)] が横流れ不安定の臨界点を予測するパラ メータとして有効であることが分かった. その結果と して, 横流れ速度の変曲点位置の高さとその位置にお ける外部流線方向渦度成分值との積の値によって, 横 流れ不安定が安定であるかどうかが簡易的に判断でき るということが示された。

（2）横流れ速度成分から得られる形状係数および 変曲点位置における無次元横流れ速度が横流れ不安定 の臨界レイノルズ数を予測するのに有効であることが 分かった. しかし, 本研究において新たに考案したパ ラメータから作成した予測関数が最も臨界レイノルズ 
数を予測するのに適していることが分かった。

（3）臨界点における擾乱の波長と境界層厚さの関 係を調べたところ, 擾乱の横流れ方向の波長が, 横流 れ方向 1\%境界層厚さの 3〜4 倍であることが分かっ た.これより推察すると, 横流れ不安定場に現れる横 流れ渦は, 横流れ方向に $3: 1 \sim 4: 1$ の楕円断面をも つ渦であると考えられる。

\section{文献}

(1) Malik, M. R., Wilkinson, S. P. and Orszag, S. A., AIAA J., 19-9 (1981), 1131-1138.

(2) Balakumar, P. and Malik, M. R., Theoret. Comput. Fluid Dyn., 2 (1990), 125-137.

( 3 ) Faller, A. J., J. Fluid Mech., 230 (1991), 245-269.

（4） 小林陵二, 機論, 46-410, B (1980), 1900-1906.

(5) Kobayashi, R. and Izumi, H., J. Fluid Mech., 127
(1983), 353-364.

(6) Poll, D. I. A., J. Fluid Mech., 150 (1985), 329-356.

( 7 ) Masad, J. A. and Malik, M. R., Phys. Fluids, 6 (1994), 2363-2379.

(8) Itoh, N., J. Fluid Mech., 317 (1996), 129-154.

(9) Högberg, M. and Henningson, D., J. Fluid Mech., 368 (1998), 339-357.

(10) Taylor, M. J. and Peake. N., J. Fluid Mech., 355 (1998), 359-381.

(11) Malik, M. R., Li, F. Choudhari, M. M. and Chang, C. L., J. Fluid Mech., 399 (1999), 85-115.

(12) Huai, X., Joslin, R. D. and Piomelli, U., J. Fluid Mech., 381 (1999), 357-380.

(13) Cooke, J. C., Proc. Camb. Phil. Soc., 46 (1950), 645-648.

(14) Betchov, R. and Criminle, W. O. Jr, Stability of Parallel Flows, (1967), 74-91, Academic Press.

（15） 江上泰広・小溜泰昭 - 小野寺達也，機論， 63-607， B (1997), 849-863.

（16） 谷口英夫・渡邊喬, 機講論, No. 991-1（1999）, 111-112. 